\title{
MECHANISM OF PARTICULATE CARRIER REACTIONS V. ADSORPTION OF HUMAN GAMMA GLOBULIN TO 0.2 MICRON DIAMETER LATEX PARTICLES AND THEIR AGGLUTINATION BY RHEUMATOID FACTOR*
}

\author{
BY \\ JACQUES M. SINGER, IRWIN ORESKES, FERENC HUTTERER, \\ AND JEROME ERNST \\ From the Department of Microbiology, Division of Laboratories, Montefiore Hospital, \\ and the Departments of Microbiology, Medicine and Pathology \\ Mount Sinai Hospital, New York
}

Polystyrene latex particles of $0.8 \mu$ diameter have been in use since 1956 for the detection of rheumatoid factors in the latex-fixation test of Singer and Plotz (1956). The use of this test or of its various modifications in rheumatoid diseases has been widespread, and this subject has been recently reviewed (Singer, 1961).

In the original procedure for the detection of rheumatoid factors, the suspension of $0.8 \mu$ diameter latex particles was sensitized by the addition of an excess of human gamma globulin (whole Fraction II). Under the conditions of the test procedure, about 90 per cent. of the added gamma globulin was not adsorbed and consequently remained in solution (Singer, Altmann, Goldenberg, and Plotz, 1960). This excess gamma globulin in the test system often resulted in variable and uncontrolled inhibition effects, thus making the test difficult to standardize and not always reproducible. More recently, several modifications have been introduced (Singer, Plotz, and Eason, 1961; Singer, Oreskes, Hutterer, and Ernst, 1962) in the original latex-fixation procedure. A smaller latex particle of $0.2 \mu$ diameter had been substituted for the previously employed $0.8 \mu$ particle. In addition, the excess unadsorbed gamma globulin remaining in solution has been removed by high speed centrifugation and washing of the coated particles.

The present report is concerned with the quantitative aspects of human gamma globulin (HGG) adsorption to the $0.2 \mu$ diameter latex particle. In addition, data on quantitative agglutination of

* This investigation was aided by grants from the National Institute of Arthritis and Metabolic Diseases, National Institutes of Health, U.S. Public Health Service, Bethesda 14, Maryland, and the New York State Chapter of the Arthritis and Rheumatism Foundation. sensitized latex particles by rheumatoid factor (RF) preparations are also reported.

\section{Material}

(1) Latex Particles: Polystyrene latex particles (LP) $0.2 \mu$ average diameter, termed Lytron 615, manufactured by the Monsanto Chemical Company. The solids content of the latex suspension was determinect gravimetrically after drying an aliquot to constant weight. The suspension was then diluted with glycine buffer $\mathrm{pH} 8 \cdot 2$ to a solids concentration of $25 \mathrm{mg} . / \mathrm{ml}$.

(2) Human Gamma Globulin (HGG): A Squibb Fraction II preparation 1812 was employed in these studies. One per cent. solutions in $0.15 \mathrm{M} \mathrm{NaCl}$ were centrifuged at $80,730 \times G$ for 1 hour. The supernatant was reserved for iodination.

(3) Radioactive Iodine: Carrier free 1-131, "iodotope", oral solution (without preservative, saline or bisulphate) from E. R. Squibb and Sons, with an activity of $1 \mathrm{mc} . / \mathrm{ml}$. was used for labelling gamma globulin or euglobulin preparations.

\section{Methods}

(1) Iodination of protein preparations used in this study was done according to the method of Boursnell, Coombs, and Rizk (1953). Excess unattached iodine was removed by passing the protein solutions through an Ioresin column (Abbott Radio-pharmaceuticals) followed by dialysis of the column effluents against several changes of glycine buffer $\mathrm{pH} 8 \cdot 2$. The 1-131 labelled HGG employed for adsorption studies had a final concentration of $6.2 \times 10^{-6}$ atom per cent. iodine.

(2) Nitrogen contents were determined by the method of Lowry, Rosebrough, Farr, and Randall (1951).

(3) Sera were obtained and pooled from twelve patients with typical rheumatoid arthritis. The individual sera exhibited F.II tanned sheep cell agglutination titres 
of from $1: 2,560$ to $1: 10,240$. A euglobulin preparation was obtained from the pooled rheumatoid arthritis sera (PRAS) in the following way:

To $50 \mathrm{ml}$. PRAS was added $450 \mathrm{ml} .1 \cdot 82 \mathrm{M}$ ammonium sulphate. After standing for $1 \mathrm{hr}$ at room temperature, the mixture was centrifuged. The supernatant, which had no rheumatoid factor activity, was discarded, and the precipitate was washed twice with $80 \mathrm{ml}$. $1.64 \mathrm{M}$ ammonium sulphate. The remaining precipitate was then dissolved in a minimum of glycine buffer $\mathrm{pH} 8 \cdot 2$, and this solution was dialysed against several changes of buffer until no sulphate ion could be detected with 1 per cent. $\mathrm{BaCl}_{2}$.

A corresponding euglobulin preparation was made in the same way from pooled normal sera (PNS) obtained from apparently healthy volunteers. The rheumatoid euglobulin fraction was further purified by sodium chloride density gradient ultracentrifugation from which the serologically active portions were retained and pooled. Corresponding fractions from the ultracentrifugation of the normal euglobulin preparation were also obtained. Finally, the ultracentrifugates of the normal and rheumatoid euglobulin were labelled with radioactive iodine. The concentration of 1-131 was found to be respectively $3.8 \times 10^{-3}$ and $1.5 \times 10^{-3}$ atom per cent.

\section{Results}

As a preliminary to other work, it was deemed necessary to determine the time dependence of HGG adsorption to the $0.2 \mu \mathrm{LP}$. The results of a typical experiment are given in Table $\mathrm{I}$.

TABLE I

TIME DEPENDENCE OF HUMAN GAMMA GLOBULIN ADSORPTION TO 0.2 MICRON DIAMETER POLYSTYRENE LATEX PARTICLES

Total volume $5 \mathrm{ml}$. containing $9 \cdot 22 \mathrm{mg}$. LP and $580 \mu \mathrm{g}$. HGG in glycine buffer $\mathrm{pH} \mathbf{8} \cdot \mathbf{2}$.

\begin{tabular}{|c|c|c|}
\hline $\begin{array}{l}\text { Time } \\
\text { (min.) }\end{array}$ & $\begin{array}{c}\text { HGG Adsorbed } \\
(\mu \mathrm{g} .)\end{array}$ & $\begin{array}{c}\text { Per cent. of } \\
\text { Maximum Adsorption }\end{array}$ \\
\hline $\begin{array}{r}5 \\
15 \\
30 \\
60 \\
120 \\
180\end{array}$ & $\begin{array}{l}502 \\
505 \\
510 \\
511 \\
512 \\
512\end{array}$ & $\begin{array}{r}98 \cdot 0 \\
98 \cdot 6 \\
99 \cdot 6 \\
99.9 \\
100 \cdot 0 \\
100 \cdot 0\end{array}$ \\
\hline
\end{tabular}

Constant amounts of 1-131 labelled HGG and latex in glycine buffer $\mathrm{pH} 8 \cdot 2$ were mixed and allowed to stand at $25^{\circ} \mathrm{C}$. for varying times from 5 to 180 minutes. The LP were then removed by high speed centrifugation (21,300 $\mathrm{G}$ for $10 \mathrm{~min}$.), and the amount of protein removed from the supernatants by adsorption to the LP was then determined from the remaining radioactivity in the supernatant. Under the conditions of this experi- ment, 88 per cent. of the added protein was eventually adsorbed. Of this amount 98 per cent. was adsorbed within 5 minutes of mixing. The remaining 2 per cent. took 1 to 2 hrs for completion. As a result, $1 \mathrm{hr}$ was chosen as optimum for gamma globulin adsorption to $0.2 \mu \mathrm{LP}$, and this time was used in all subsequent experiments.

In an attempt to determine the number of washings sufficient to remove excess HGG from the coated $0.2 \mu \mathrm{LP}$ suspension, varying amounts of HGG were added to $5 \mathrm{mg}$. LP solids in a volume of $5 \mathrm{ml}$. glycine buffer $\mathrm{pH} 8 \cdot 2$. After one hour at $25^{\circ} \mathrm{C}$. the particles were sedimented by centrifugation, and the supernatants were removed. The particles were then resuspended in $5 \mathrm{ml}$. buffer using a Vortex mixer. After $1 \mathrm{hr}$ the mixture was centrifuged and the supernatant wash removed. This washing procedure was carried out four times. It was found that most of the added HGG depending on original concentration remained in the supernatant. The first wash also removed considerable amounts of protein, and the second wash considerably less. Further washings removed very little more protein, and it was concluded that two washings were sufficient to remove excess or easily desorbed HGG from the latex particles.

The Figure is a graphical representation of quantitative adsorption of $\mathrm{HGG}$ to $5 \mathrm{mg}$. amounts of $0.2 \mu \mathrm{LP}$ but with varying amounts of added HGG.

The upper curve represents total adsorption as determined by counting supernatants after centrifugation of the coated latex particles. The lower curve represents HGG adsorption after the particles

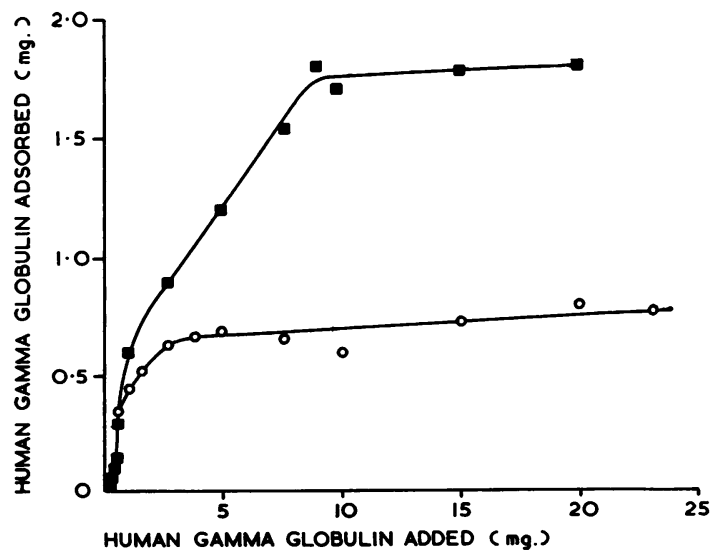

Figure.-Adsorption of human gamma globulin to $\mathbf{0 . 2}$ micron diameter latex particles. Volume, $5 \mathrm{ml}$; $\mathrm{pH} 8 \cdot 2 ; 5 \mathrm{mg}$. latex; $0 \cdot 15$ ionic strength.

Total HGG adsorption.

HGG still adsorbed after two washings. 
have been twice washed with $5 \mathrm{ml}$. glycine buffer pH 8.2. The latter data was obtained by suspending the twice-washed particles in buffer, drying the suspension in a planchet, and counting the dried suspension.

A summary and analysis of these adsorption results are given in Table II. Under the experimental conditions employed, a maximum adsorption of $0.36 \mathrm{mg}$. HGG per mg. $0.2 \mu$ LP was obtained. Of this amount only $0 \cdot 15 \mathrm{mg}$. HGG or $41 \cdot 6$ per cent. remained on the particles after two washings. These data correspond to 5,840 HGG molecules per $0.2 \mu$ LP originally adsorbed and 2,430 molecules per particle still adsorbed after two washings. It will be seen later that this latter value represents a more than 300 -fold excess of potential reactive sites over the number actually required for agglutination by rheumatoid factor. These values were arrived at by the following calculation:

$$
\frac{\text { HGG adsorbed }(\mathrm{g} . / \mathrm{mg} . \mathrm{LP}) \times 6.02 \times 10^{23}}{1.6 \times 10^{5} \times 2.32 \times 10^{11}},
$$

where $1.6 \times 10^{5}$ is the molecular weight of HGG, and $2.32 \times 10^{11}$ is the number of particles in a milligram of $0.2 \mu$ diameter latex solids.

The latter value was calculated as follows:

$$
1 \times 10^{-3} \text { g. } / 4 \cdot 189 r^{3} D
$$

where $4 \cdot 189 r^{3}$ is the volume of a sphere; $r$ is $1 \times 10^{-5} \mathrm{~cm}$., the particle radius; and $D$ is $1 \cdot 03$, the particle density.

TABLE II

ANALYSIS OF HUMAN GAMMA GLOBULIN ADSORPTION TO $0 \cdot 2$ MICRON DIAMETER POLYSTYRENE

\begin{tabular}{|c|c|}
\hline Maximum HGG adsorption & $\begin{array}{l}3.6 \times 10^{2} \mu \mathrm{gg} . / \mathrm{mg} . \mathrm{LP} \\
5.8 \times 10^{3} \mathrm{molecules} / \text { particle } \\
1.30 \mu \mathrm{g} . \mathrm{cm} .2\end{array}$ \\
\hline $\begin{array}{l}\text { Adsorbed HGG remaining after } \\
\text { two washings }\end{array}$ & $\begin{array}{l}1.5 \times 10^{2} \mu \mathrm{g} . / \mathrm{mg} . \mathrm{LP} \\
2.4 \times 10^{3} \mathrm{molecules} / \mathrm{particle} \\
0.54 \mu \mathrm{g} . / \mathrm{cm} .2\end{array}$ \\
\hline $\begin{array}{c}\text { Adsorbed 7S HGG in first layer: } \\
\text { on } 0.22 \mu \text { diameter LP* } \\
\text { on } 0.802 \mu \text { diameter LP* }\end{array}$ & $\begin{array}{l}0.69 \mu \mathrm{g} . / \mathrm{cm} .^{2} \\
0.67 \mu \mathrm{g} . / \mathrm{cm} .^{2}\end{array}$ \\
\hline $\begin{array}{l}\text { Adsorbed heated }\left(56^{\circ} \mathrm{C} .1 \mathrm{hr}\right) \\
7 \mathrm{~S} \text { HG in first layer on } \\
0 \cdot 802 \mu \text { diameter LP† } \\
\text { Adsorbed heated }\left(63^{\circ} \mathrm{C} .5-8 \mathrm{~min} .\right) \\
\text { HGG on 0.81 } \mu \text { diameter } \\
\text { LP remaining after three } \\
\text { washings } \neq\end{array}$ & $\begin{array}{l}0.84 \mu \mathrm{g} . / \mathrm{cm} . .^{2} \\
1.07 \mu \mathrm{g} . / \mathrm{cm} .{ }^{2}\end{array}$ \\
\hline $\begin{array}{l}\text { Adsorbed crystalline bovine serum } \\
\text { albumin on } 0 \cdot 81 \mu \text { diameter } \\
\text { LP remaining after three } \\
\text { washings } \ddagger\end{array}$ & $0.52 \mu \mathrm{g} . / \mathrm{cm} .2$ \\
\hline
\end{tabular}
LATEX PARTICLES

* Calculated from data at pH 9.01 of Oreskes and Singer (1961). $\dagger$ Determined at pH 9.01 according to the procedures in Oreskes and Singer (1961).

$\ddagger$ Calculated from data at $\mathrm{pH} 8 \cdot 2$ of Bernhard, Cheng, and Talmage (1962).
The amount of protein adsorbed per unit of particle surface area was also calculated (Table II). This was done in order to facilitate comparison between the present data with previously reported data for HGG adsorption to latex particles of other sizes (Oreskes and Singer, 1961; Bernhard, Cheng, and Talmage, 1962). Oreskes and Singer (1961) suggested that HGG is adsorbed as a double molecular layer to latex particles. Their data reported for "first layer" adsorption has been converted to $\mu \mathrm{g}$. per square centimeters and is equal to a mean value of $0.68 \mu \mathrm{g}$. $\mathrm{HGG} / \mathrm{cm}^{2}$. The presently reported value of $0.54 \mu \mathrm{g}$. $\mathrm{HGG} / \mathrm{cm} .^{2}$ is about 20 per cent. lower, but this may be due to the fact that it was the protein still adsorbed after two washings, whereas the higher value was derived from equilibrium measurements. In any event the present data appears to be consistent with previous conclusions that HGG is adsorbed to latex particles in two layers or in two phases characterized by different affinities for the particles.

The data reported here is at variance with that recently reported by Bernhard, Cheng, and Talmage (1962). Their data for HGG adsorption to $0.81 \mu$ diameter LP corresponded to $1.07 \mu \mathrm{g}$. $\mathrm{HGG} / \mathrm{cm} .^{2}$ after washing. However, they reported that their HGG sample was heated at $63^{\circ} \mathrm{C}$. for 5 to 8 minutes $\vec{\varnothing}$ before use. Studies in this laboratory of $7 \mathrm{~S} \mathrm{HG}$. adsorption after heating the protein solution f@i. $1 \mathrm{hr}$ at $56^{\circ} \mathrm{C}$. yielded a first layer value of $0.8 \overline{4}$ $\mu \mathrm{g}$. HGG $/ \mathrm{cm} .{ }^{2}$ as compared with 0.67 for the unheated sample under the same conditions. Thus it appears that heating of HGG (which is known to produce denaturation and aggregation) before adsorption increases the total amount of protein that can be adsorbed per unit surface area. The difference between the present data and that cited above may therefore be due to differences in aggregate content in the HGG samples used. The study by Bernhard and others (1962) of (apparently unheated) crystalline bovine serum albumin adsorption to latex particles yielded a value of 0.52 $\mu \mathrm{g} . / \mathrm{cm}{ }^{2}$ which corresponds closely to our value of $0.54 \mu \mathrm{g} . / \mathrm{cm} .{ }^{2}$ for unheated HGG. These various data are summarized in Table II.

In an attempt to determine the minimum number of rheumatoid factor molecules required to agglutinate $0.2 \mu \mathrm{LP}$, the adsorption of euglobulin 0 preparations from pooled normal and rheumatoid $N$ sera to HGG coated latex particles was studied. N Varying amounts of radioactive 1-131 labelled normal or rheumatoid euglobulin were mixed with $0.25 \mathrm{mg}$. untagged HGG coated $0.2 \mu \mathrm{LP}$ in a volume of $2 \mathrm{ml}$. glycine buffer $\mathrm{pH} 8 \cdot 2$. The mixtures were allowed to stand for $24 \mathrm{hrs}$ in the 
refrigerator and agglutination was noted. The latex particles in all tubes, whether agglutinated or not, were sedimented by centrifugation, washed twice with $2 \mathrm{ml}$. buffer, and resuspended in $2 \mathrm{ml}$. buffer. The particle suspension was then counted for adsorbed radioactive protein. The results are presented in Table III. In all cases there was greater adsorption of rheumatoid euglobulin than of the normal, even where no agglutination was observed. The difference in adsorption between the two euglobulin preparations was calculated and showed a consistent rise with euglobulin concentration.

TABLE III

SUMMARY OF NORMAL AND RHEUMATOID EUGLOBULIN ADSORPTION TO HGG-COATED 0.2 MICRON DIAMETER LATEX PARTICLES

\begin{tabular}{|c|c|c|c|c|c|}
\hline \multirow{2}{*}{$\begin{array}{c}\begin{array}{c}\text { Euglobulin } \\
\text { Added }\end{array} \\
\begin{array}{c}\text { Normal } \\
\text { or } \\
\begin{array}{c}\text { Rheumatoid } \\
(\mu \mathrm{g} .)\end{array}\end{array}\end{array}$} & \multicolumn{3}{|c|}{ Euglobulin Absorbed } & \multirow[b]{2}{*}{$\begin{array}{l}\text { Aggluti- } \\
\text { nation* }\end{array}$} & \multirow[b]{2}{*}{$\begin{array}{c}\text { RF } \\
\text { Molecules } \\
\text { Fixed } \\
\text { per } \\
\text { Latex } \\
\text { Particle }\end{array}$} \\
\hline & $\begin{array}{c}\text { Rheu- } \\
\text { matoid } \\
(\mu \mathrm{g} .)\end{array}$ & $\begin{array}{c}\text { Normal } \\
(\mu \mathrm{g} .)\end{array}$ & $\begin{array}{l}\text { Rheumatoid } \\
\text { minus } \\
\text { Normal } \\
\text { Euglobulin } \\
\text { Adsorption } \\
\text { ( } \mu \text { g.) }\end{array}$ & & \\
\hline $\begin{array}{r}75.0 \\
50.0 \\
25.0 \\
10.0 \\
5.0\end{array}$ & $\begin{array}{l}3 \cdot 36 \\
2 \cdot 81 \\
1 \cdot 76 \\
0 \cdot 69 \\
0 \cdot 32\end{array}$ & $\begin{array}{l}2 \cdot 67 \\
2 \cdot 29 \\
1 \cdot 39 \\
0.47 \\
0.25\end{array}$ & $\begin{array}{l}0.69 \\
0.52 \\
0.37 \\
0.22 \\
0.07\end{array}$ & $\begin{array}{l}+4 \\
+3 \\
+1 \\
-\end{array}$ & $\begin{array}{l}7 \cdot 3 \\
5 \cdot 4+ \\
3 \cdot 8+ \\
2 \cdot 3 \\
0 \cdot 7\end{array}$ \\
\hline
\end{tabular}

* Complete agglutination, +4 ; partial agglutination, +3 to +1 Agglutination was obtained only with rheumatoid euglobulin.

+ These are average values. The number of $\mathbf{R F}$ molecules adsorbed to the agglutinated particles only was not determined.

On the assumption that the differences in total adsorption are due only to rheumatoid factor (RF) fixation, these values have been converted to rheumatoid factor molecules fixed per latex particle. The calculation was done as previously indicated, except that the molecular weight of RF was taken as $1 \times 10^{6}$. At a ratio of about $3 \mathrm{RF}$ molecules per LP, no agglutination was observed. Partial agglutination was obtained in the range of 4 to 6 molecules per particle and complete agglutination at 7 or 8 molecules per particle. Clearly the validity of these results depends upon the assumption of equal nonspecific adsorption of the two preparations studied. Support for these results may, however, be derived from the data of Heimer, Federico, and Freyberg (1958), who observed that $0.026 \mu \mathrm{g}$. of a highly purified Macroglobulin I preparation still yielded agglutination in the standard latex-fixation test. This value corresponds to 34 RF molecules $/ \mu^{2}$ of particle surface area. Our values of $7 \cdot 3 \mathrm{RF}$ molecules adsorbed per particle at complete agglutination corresponds to 58 mole- cules $/ \mu^{2}$. Noting that our preparation presumably contains all RF species (not just Macroglobulin I) and that Heimer's data is derived from 2-fold serial dilution experiments, the correspondence between the two results appear reasonable. These data suggest that the number of RF molecules required for complete agglutination is proportional to the total surface area of the sensitized latex particles employed.

A further comparison may be made with the work of Roberts and Haurowitz (1962). They found that bovine serum albumin (BSA) sensitized rabbit erythrocytes, when agglutinated by anti-BSA rabbit globulin, fixed a minimum of about $1 \times 10^{5}$ antibody molecules per red cell. Taking the surface area of a rabbit erythrocyte as $110 \mu^{2}$ (Ponder, 1948), this is equivalent to 91 antibody molecules/ $\mu^{2}$. In spite of the many obvious differences between the latex and the rabbit erythrocyte agglutinating systems, this correspondence is comparatively close. From these various data, it appears that, in agglutinating systems containing a large number of excess antigen sites, the minimum number of antibody molecules fixed at complete agglutination is proportional to the surface area of the system. Apparently agglutination will not occur unless a minimum number of fixed antibody molecules are available for forming interparticle links.

\section{Summary}

Human gamma globulin (HGG) adsorption to $0.2 \mu$ diameter latex particles (LP) is quite rapid with 98 per cent. of the total taken up within 5 min., and the remainder in about $1 \mathrm{hr}$. Adsorption appears to be in the form of a double molecular layer with the outer layer easily desorbed by washing and with the inner layer more strongly held and not readily desorbed by washing. The amount of nondesorbable protein increases if the HGG preparation is heated before coating. HGG-coated washed $0.2 \mu \mathrm{LP}$ carry at least $2.4 \times 10^{3}$ protein molecules adsorbed to their surface, but only seven or eight rheumatoid factor molecules fixed per particle are sufficient for complete agglutination.

The authors gratefully acknowledge the excellent technical assistance of Mrs. Evelyn Eason.

\section{REFERENCES}

Bernhard, G. C., Cheng, W., and Talmage, D. W. (1962). J. Immunol., 88, 750.

Boursnell, J. C., Coombs, R. R. A., and Rizk, V. (1953). Biochem. J., 55, 745.

Heimer, R., Federico, O. M., and Freyberg, R. H. (1958). Proc. Soc. exp. Biol. (N.Y.), 99, 381. 
Lowry, O. H., Rosebrough, N. J., Farr, A. L., and Randall, R. J. (1951). J. biol. Chem., 193, 265.

Oreskes, I., and Singer, J. M. (1961). J. Immunol., 86, 338.

Ponder, E. (1948). "Hemolysis and related phenomena", p. 14. Grune and Stratton, New York.

Roberts, A. N., and Haurowitz, F. (1962). J. Immunol., 89, 348.

Singer, J. M., and Plotz, C. M. (1956). Amer. J. Med., 21, 888 .

—, Altmann, G., Goldenberg, A., and Plotz, C. M. (1960). Arthr. and Rheum., 3, 515.

(1961). Amer. J. Med., 31, 766.

-, Plotz, C. M., and Eason, E. (1961). "Atti del $X$ Congresso della Liga Internazionale contro il Reumatismo", vol. 1, p. 304.

- Oreskes, I., Hutterer, F., and Ernst, J. (1962). Arthr. and Rheum., 5, 122.

Mécanisme des réactions á porteur particulaire. V. Adsorption de la globuline gamma humaine aux particules de latex de diametre de 0,2 micron et leur agglutination par le facteur rhumatismal

RÉSUMÉ

L'adsorption de la globuline gamma humaine (HGG) aux particules de latex (LP) de diamètre de 0,2 micron est assez rapide: 98 pour cent de celle-ci est relevée au bout de 5 minutes et le reste au bout d'une heure environ.
Cette adsorption semble se faire en deux couches moléculaires; la couche externe se détache facilement au lavage mais non pas la couche interne. La quantité de protéine non-détachable augmente si l'on chauffe la préparation de HGG avant l'enduisage. Les particules de latex de 0.2 micron, enduites de $\mathrm{HGG}$ et lavées, portent au moins $2,4 \times 10^{3}$ molécules de protéine adsorbées à leur surface, mais seulement 7 ou 8 molécules du facteur rhumatismal fixées par le particule sont suffisants pour obtenir una agglutination complète.

El mecanismo de las reacciones mediante particulas portadoras. V. Adsorción de la globulina gamma humana por particulas de latex de diametro de 0,2 de micrón y su aglutinación por el factor reumatoide

\section{Sumario}

La adsorción de la globulina gamma humana (HGG) a partítulas de latex (LP) de diametro de 0,2 de micrón $\mathrm{N}$ es bastante rápida; un 98 por ciento se ve recogido al ó cabo de 5 minutos y lo demás cerca de una hora más tarde. Esta adsorción parece acabarse en dos capas $\underset{\perp}{\triangle}$ moleculares; la capa externa se desprende fácilmente con 응 el lavado pero la capa interna se mantiene mucho mejor y resiste más al lavado. La proporción de la proteina "pegada" aumenta al calentar la preparación de HGG Z antes de la adsorción. Las partículas de latex de 0,2 de micrón, cubiertas de HGG y lavadas, llevan al menos $2,4 \times 10^{3}$ moléculas de proteina adsorbidas a su superficie, pero sólo 7 u 8 moléculas del factor reumatoide $\mathbb{\Phi}$ fijadas por una partícula bastan para obtener ung $\vec{\circ}$ aglutinación completa. 